\title{
OBITUARIES
}

\section{Sir lan Richmond}

I. A. Rrchmond, professor of the Archaeology of the Roman Empire in the University of Oxford, died on October 4 at the age of sixty-three. He was educated at Ruthin School and Corpus Christi College, Oxford. Studentships from his university and the British School at Rome enabled him to engage for two years after graduation in field research centred on Rome. In 1926 he was appointed lecturer in classical archaeology and ancient history at Queen's University, Belfast, whence he returned to Rome as director of the School. In 1935 he was appointed to a post in Roman-British history and archaeology in the Newcastle upon Tyne Division of the University of Durham, where he remained, as lecturer, as reader and as professor, until 1956, when he accepted the post in Oxford which he held until his death. He received a knighthood in 1964, the same year as he became president of the Society of Antiquarios of London.

Richmond had few equals either in investigation or in oxposition. Almost all aspects of Roman provincial archaeology have been enriched or illumined by his activity, and he has been justly acknowledged for several years as tho leading authority in a by no means narrow field.

The twin son of a Lancashire surgeon, Richmond sometimes compared his own work as an excavator with that of a surgeon. He had a flair for, and much experience in, the study of structural evidence. This enabled him to be economically selective in an excavation and still to obtain the full picture, as he did that of the legionary fortress at Inchtuthil in Perthshire, a little at a time over fourteen years. The method was only successful in his own hands, for less skilled excavators require a bolder approach. Richmond would excavate boldly when occasion demanded, and strip off a whole site level by level. Excavators the world over have benefited from working with him on the Corbridge training courses, where he tought techniques by example rather than precept.

On Hadrian's Wall, Richmond provided the sustained effort which brought to fruition programmes of research sometimes initiated by others and carried through in collaboration. In the decade before and the years immediately after the Second World War, problems which had remained obdurate for generations were tackled in a scientific spirit and solved finally and eonvincingly. The Museum of Antiquities in Newcastle upon Tyne, which he opened in 1960, was largely his ereation, and is a pormanent monument to him.

Richmond was a first-class teacher, but never surrounded himself with a large circle of undergraduates or recent graduates; for good or ill that was not his way. He was given honorary degrees by six universities, including that where ho had spent half his working life. Learned societies and univorsities also honoured him by asking him to deliver endowed and named lectures. He will be remembered by a wider public for the hundreds of lectures, illustrated, delivered without a script out of the depth of his knowledge, sound, clear and gravely gay, which ho gave, up and down the country, to any interested audience.

$\mathrm{He}$ held tho highest office in national societies, and was a valued member of national boards and commissions in both England and Scotland; he also found time, when already a busy man, to hold office in local societies and to serve on committeos and councils. He was no passenger on these bodies, and his cheerful common sense was much in demand. He used the time on the long train journeys to draft his reports.

Richmond's published work includes The City Wall of Imperial Rome (1930), a substantial contribution to the
Northumberland County History-The Romans in Redes. dale (1940), the tenth (1947) and eleventh (1957) editions of the Handbook to the Roman Wall, Roman Britain (Collins, 1947), Roman Britain (Pelican, 1955), and Roman and Native in North Britain (1958). Excavation reports, illustrated by his own photographs and drawings, and substantial papers on many different facets of his main subject, are to be found in the journals of local and national societies.

$\mathrm{He}$ was not merely an able man, but a good man. He took an unconcealed delight in success, but was never ambitious at the expense of others. $\mathrm{H}_{e}$ would spend hours with the writer of a paper or report going through it with him sentence by sentence improving the language. On meeting an acquaintance he never failed to ask the right question about himself and his family. He could be stern, but was always open; his normal mood was of robust good humour and impish wit. He would help a friend or colleague when he needed it most and seemed to deserve it least. It was his explicit policy to do things for other people; he did so as if he were indefatigable, which unfortunately he was not. J. P. GILLAM

\section{K. R. Butlin}

Kenneth Rupert Butlin died on October 1, 1965, at the age of sixty-eight. He was educated at Oundle School and, with an interruption for military service, at Trinity College, Cambridge. Shortly after the First World War he took a first in chemistry and almost immediately left for Argentina, where he worked on the fermentation of sugar. Thereafter he remained interested in the chemical activities of micro-organisms and, returning to the United Kingdom in 1929, he joined A. C. Thaysen's group of microbiologists, then working at the Royal Naval cordite factory at Holton Heath. This group was transferred as a unit to the Chemical Research Laboratory, Teddington, in 1933, and it was from Teddington that Butlin published the research for which he will be most remembered.

His earliost papers were concerned with the chemical activities of the acetic acid bactoria, and his review of these organisms is still required reading for those interosted in tho subject. During the Second World War, Butlin, with the rest of Thaysen's group, turned his attention to the problem of food yoast production, making use of molasses, a project which gave him valuable experience of large-scale production of microbes and which involved, incidentally, one of the earliest uses of continuous culture. At the end of the War, Thaysen and H. J. Bunker (a leading authority on the sulphur bacteria) loft Teddington, and research on microbiology at the Chemical Research Laboratory was left, in the hands of a small section of the Corrosion Group, headed by Butlin, studying bacterial corrosion. This process is largely the responsibility of the sulphate-reducing bacteria (Desulfovibrio), and Butlin's small group rapidly established themsolves as leading authorities in this field: they were, for example, among the first to work with authentically pure bacterial cultures.

The then director of the Chemical Research Laboratory, R. P. (now Sir Patrick) Linstoad, perceiving the broader ramification of chemical microbiology, initiated the expansion of Butlin's microbiology section until, in the early 1950 's, it became an independent Microbiology Group, mainly concerned with the study of sulphatereducing bactoria but also with a variety of bactoria of economic and industrial importance. In 1950, Butlin accepted responsibility for a few hundred bacterial cultures of industrial importance which the National Collection of Type Cultures proposed to discard, and thus 
founded the National Collection of Industrial Bacteria, now located at the Torry Research Station, Aberdeen. The 1950's were the most productive period of Butlin's career: his Group worked on such strictly practical topics as the feasibility of producing sulphur on an industrial scale with the aid of bacteria, control of pollution in waterlogged gravel and clay pits, bacterial leaching of ores, bacterial contamination of petroleum; topics of less-direct applicability such as the mechanism of microbial oxidation of phenols (important in biological effluent treatment) and the continuous culture of anaerobes; relatively acadernic matters, though still having a practical background, such as the biochemistry of sulphatereducing bacteria and the mechanism of the mothane fermentation. By 1958, Butlin's Group was the major British research unit concerned with basic economic microbiology. The blow to British research, resulting from its disbandment by the Research Council of the Department of Scientific and Industrial Research, reverberated throughout the scientific world; it still ovokes strong opinions among microbiologists, both here and abroad. Having staunchly resisted the disbandment of his Group, Butlin was compulsorily rotired from the Sciontific Civil Service in 1959, but, undismayed, he often emerged from retirement to undertake consultant work or to attend scientific meetings.

Butlin's conviction that microbes are of the greatest potential importance to industry, not only in production but also in the deterioration or disposal of industrial products, was fundamental both to his work and his scientific reputation. He was also a man of striling personality and culture. He was a great lover of opera; he enjoyod travel, good food, wine and companionship; he was firmly literate in the sense that he believed that, if work was worth writing up, it was worth writing well. The literary standard of his publications and, perforce, those of his Group, was high. But, most of all, he had an enormous capacity to enjoy life, an ability which he never failed to communicate to his companions, so that even quite solemn or troublesome occasions took on the character of a party or a convivial gathering. His personality inspired strong affection and he will be sadly missed, not only by his intimate friends, but by innumer. able acquaintances and scientific colleagues all over tho world on whom his sunny and friendly disposition made an unforgettable impact. His wife, née Helen Mary Fletcher, survives him; their son, Martin, is an assistant keeper at the Tate Gallery.

\section{Prof. H. Schardin}

Prof. Hubert Schardin, ministerial director, Ministry of Defence, Bonn, honorary director of the Franco. German Research Institute at Saint-Louis, and director of the Ernst Mach Institute at Froiburg-im-Breisgaw and Weil-am-Rhein, died on September 27, aged sixtythree.

Prof. Schardin was a good scientist and a fine man who inspired many to both scientific effort and to inter. national understanding. The situations already mentioned do not include tho capacities by which I bost knew him. He was the German delegate to the International Congress on High Spoed Photography, Europeau pivot of this subject, one of the very fow present at all such congresses so far and to many a legend in his own. lifetime.

His whole career had been devoted to, first, ballistics. leading naturally to high-spoed photography-Schlieren investigations in particular-and to philosophic interost in time. He joined Cranz in Berlin in the mid-1920's-. and their association will always be remembered for their multiple spark, multiple camera technique of 1928 known simply as the Cranz-Schardin system and used in overy laboratory which investigates projectiles in their many guises.

Cranz provides the link from to-day back to the scientific era of the nineteenth century and such names as Toepler and Mach, just as Schardin is a strong link to the earlier decades of this century.

When Cranz retired in 1935 , Schardin took over as the German leader in ballistic photography and was in charge of the Ballistic Institute of the Technical Academy of the. German Air Foree from then until 1945. Later, the Franco-German Research Institute at Saint-Louis was founded with Schardin as its director. The works of this Institute, its director and his colleagues speak for themselves.

Prof. Schardin will be missed and remembered affectionately by many people in many countries, and especially by those interested in the same disciplines and philo. sophies. The British National Committee for High Speed Photography believes that a prize in his honour should be presented at International Congresses on High Speed Photography for worthy contributions to the subject. It could be known simply as the "Schardin Award", and the British Committee would be pleased to support such a commemoration.
G. H. LuNN

\section{NEWS and VIEWS}

The Royal Society of London: Award of Royal Medals

Her MaJesty The QUEEn has been graciously pleased to approve recommendations made by the Council of the Royal Society for the award of the three Royal Medals for the present year as follows: to Dr. R. A. Lyttleton, reador in theoretical astronomy in the University of Cambridge (presently at the Institute of Astrophysies, Brandeis University, Waltham, Massachusetts, U.S.A.), for his distinguished contributions to astronomy, particularly for his work on the dynamical stability of galaxios; to Dr. J. C. Kendrow, deputy chairman of the Medical Research Council Laboratory of Molecular Biology, Cambridge, for his distinguished contributions to tho complete structural analysis of a protein molecule (myoglobin), particularly the biological aspects of this study; to Dr. H. C. Husband, chartered civil engineer (of Messrs. H. C. Husband and Co., Sheffield), for his distinguished work in many aspects of engineering, particularly for his design studies of large structures such as those oxemplified in the radio telescopes at Jodroll Bank and Goonhilly Downs.

Mathematics in the University of Edinburgh : Prof. A. C. Aitken, F.R.S.

Prof. A. C. Attken has retired from the chair of mathematics in the University of Edinburgh, where he has boon a lecturer and reader from 1925, and where he succeoded Sir Edmund Whittaker as professor in 1946. Born and educated in Now Zealand, Aitken went to Edinburgh in 1923 at the age of twenty-eight as a research student, accompanied by his wife. There he received in 1925, not the degreo of Ph.D. for which he was registored, but that of D.Sc., for a thesis recognized as boing of quite outstanding originality and merit. No doubt his phenomenal powers of mental arithmetic provided the original impetus which led him, both in this thesis and later in many published papers, to devote so much of his life work to practical mathematies and numorical analysis. He has 